\title{
Flower nectary structure in Cornus alba $\mathbf{L}$.
}

\author{
Agata Konarska
}

Received: 17 February 2010/Accepted: 6 September 2010/Published online: 8 October 2010

(C) The Author(s) 2010. This article is published with open access at Springerlink.com

\begin{abstract}
The structure of the floral nectaries of Cornus alba was studied using light microscopy as well as scanning and transmission electron microscopy. It was found that the nectary gland of white dogwood had the shape of a fleshy ring surrounding the base of the style of the inferior ovary. Nectar secretion occurs through slightly depressed stomata, evenly distributed in the epidermis of the nectary. The nectariferous tissue is composed of over a dozen layers of heterogeneously structured cells. Between groups of cells with a typical structure, characteristic for the secretory tissue, cells occur with degenerated content and a high degree of vacuolization. In the area of the nectary gland cells, no vascular tissue elements were observed. The nectary was irrigated by the vasculature of the flower receptacle.
\end{abstract}

Keywords Cornaceae $\cdot$ Cornus alba $\cdot$ Nectary $\cdot$ Structure

\section{Introduction}

The genus dogwood (Cornus), belonging to the family Cornaceae, includes about 50 species native to the Northern Hemisphere, found primarily in the northern temperate zones. These are usually trees or shrubs, rarely herbaceous plants, with opposite leaves, being winter deciduous, and frequently with underground rhizomes. In Poland the most well-known species are C. alba and C. florida, grown as ornamental species, as well as $C$. mas, which is used for decorative purposes but also has culinary and medicinal

A. Konarska $(\bowtie)$

Department of Botany, University of Life Sciences in Lublin, Akademicka 15, 20-950 Lublin, Poland

e-mail: agata.konarska@up.lublin.pl uses (Hofman 1995; Szweykowska and Szweykowski 2003). White dogwood (C. alba) is native to Mongolia, Russia, Korea, China, and Japan. It has inconspicuous yellow-white flowers clustered in cymose corymbs. The number of inflorescence is variable (on average 89). It flowers from May to June, but single inflorescences appear at the end of the stems until late autumn. The lifespan of a single flower is 3 days (Konarska 2009). Flowers of C. alba, similarly to other dogwood species, are furnished with a well-exposed nectary located at the top of the inferior ovary and surrounding the style. The flowers are characterized by a delicate scent, which is characteristic for entomophilous plants (Cronquist 1988; Eyde 1988; Murrell 1993; Beck 2005; Nicolson et al. 2007; Zhuang et al. 2008; Mert and Soylu 2009). The pollinators of C. alba are Hymenoptera (mainly bees and andrenids) as well as Diptera and Coleoptera (Konarska 2009).

Because Cornus alba tolerates well-moist, marshy areas and is very resistant to smoke and air pollution, it is abundantly planted in housing estates in industrial centers in Poland and throughout Europe (Szweykowska and Szweykowski 2003; Seneta and Doaltowski 2004). No data were found on the usefulness of $C$. alba as a spring source of nectar and pollen for pollinating insects, and there is no information about the structure of the floral nectaries of Cornus. Therefore, the aims of this research are to study nectary structure and nectar production of Cornus alba using different microscopy techniques.

\section{Materials and methods}

The study was conducted in 2009 at the Botanical Garden of the Maria Curie-Skłodowska University in Lublin, Poland. The study material comprised Cornus alba L. 
flowers, sampled the first day after petal opening; anthers were open, and a glistening secretion was visible on the top of the nectary.

Observations of the structure of the floral nectaries were made using light microscopy as well as scanning and transmission electron microscopy.

\section{Scanning electron microscopy (SEM)}

Ovaries with their accompanying nectary disc were fixed in $2 \%$ solution of glutaraldehyde with $2.5 \%$ paraformaldehyde in $0.75 \mathrm{M}$ phosphate buffer ( $\mathrm{pH}$ 6.8) at temperature of $4^{\circ} \mathrm{C}$ for $12 \mathrm{~h}$. Subsequently, the samples were dehydrated in an ethanol series and dried at the critical point in liquid $\mathrm{CO}_{2}$. Using a CS 100 sputter coater, they were coated with gold. The preparations were observed using a Tescan Vega II scanning electron microscope. The number of stomata per $\mathrm{mm}^{2}$ was counted using the Morphology program.

\section{Light microscopy (LM)}

The anatomical observations of the nectaries were based on semithin transverse and longitudinal sections. The sections were stained with $1 \%$ methylene blue with $1 \%$ azur II in $1 \%$ aqueous solution of sodium tetraborate. The material was fixed and embedded in synthetic resin with the standard method used in transmission electron microscopy. Sections were observed by means of a Jenaval contrast microscope.

\section{Transmission electron microscopy (TEM)}

Flower fragments with nectaries were fixed in $2 \%$ paraformaldehyde and $2.5 \%$ glutaraldehyde buffered at $\mathrm{pH} 7.4$ in $0.1 \mathrm{M}$ cacodylate buffer. Fixation was performed at room temperature for $2 \mathrm{~h}$, followed by $12 \mathrm{~h}$ at $4^{\circ} \mathrm{C}$. When fixed, the samples were rinsed with $0.1 \mathrm{M}$ cacodylate buffer at $4^{\circ} \mathrm{C}$ for $24 \mathrm{~h}$ and then treated with $1 \% \mathrm{OsO}_{4}$. Subsequently, the samples were transferred to redistilled water and stained with $0.5 \%$ aqueous solution of uranyl acetate. After passage through increasing concentrations of propylene oxide in ethanol and finally through pure propylene oxide, the samples were embedded for $12 \mathrm{~h}$ in Spurr low-viscosity resin at $70^{\circ} \mathrm{C}$. Ultrathin sections $(60 \mathrm{~nm}$ thick) were treated with $8 \%$ solution of uranyl acetate in acetic acid and with lead citrate (Spurr 1969). Images were observed and recorded using a Tesla BS-500 transmission electron microscopy.

\section{Results}

C. alba flowers, $8-10 \mathrm{~mm}$ in diameter, have a four-sepalled inconspicuous calyx and four cream-white petals with
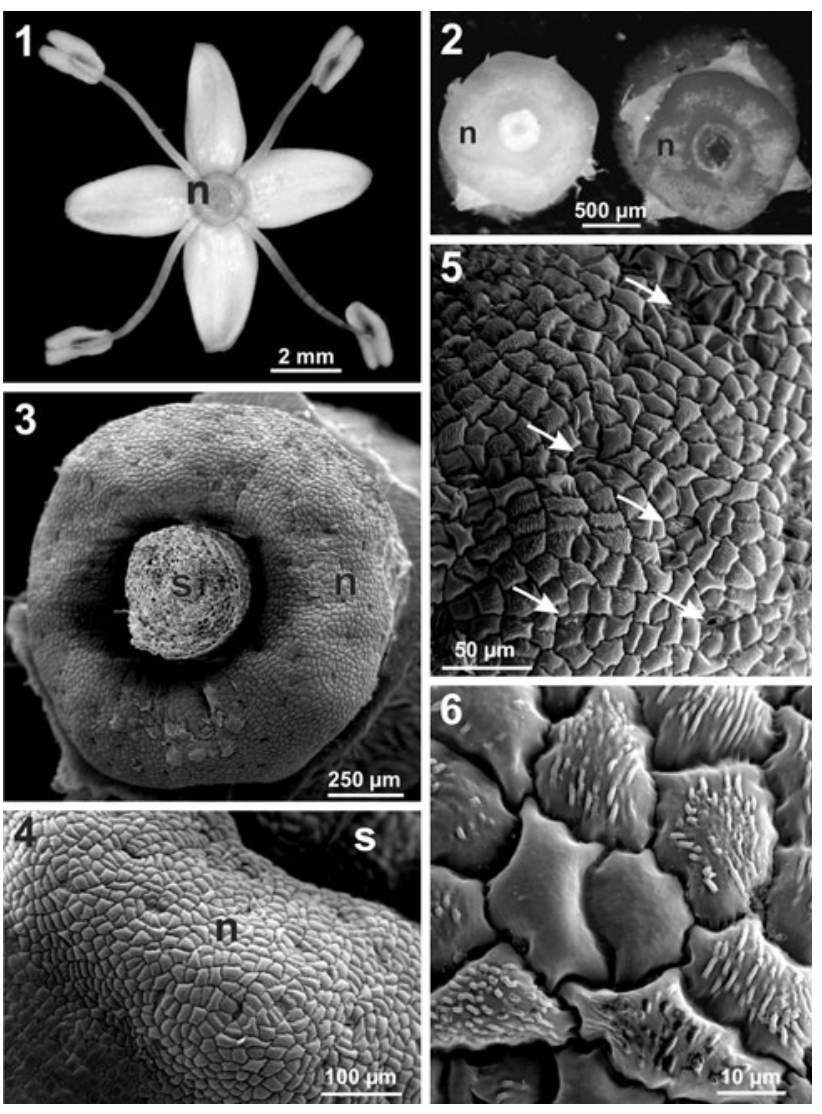

Plate I Fig. 1 Flower of Cornus alba with a nectary ( $n)$ on top of the ovary surrounding the style. Fig. 2 Fragments of Cornus alba flowers with the nectary $(n)$. Note the change of nectary color after the end of the flowering period. Figs. 3, 4 SEM. Nectary $(n)$ of $C$. alba. $s$ style. Figs. 5, 6 SEM. Fragments of the surface of the secretory epidermis of the C. alba floral nectary. Note stomata (arrows) and striated cuticle

silky sheen, as well as four stamens, alternating with the petals of the corolla, with bright yellow anthers and long stamen filaments (Fig. 1). The ovary is inferior, and the base of the style is surrounded by a disc-like nectary with diameter $\sim 1.5 \mathrm{~mm}$ and height $\sim 0.5 \mathrm{~mm}$ (Figs. 1-4). Nectar secretion starts 1 day before petal opening and lasts 4 days. At the end of the secretion stage, shortly before petal and stamen abscission, the color of the nectary gland changes from crème-yellow to pink-red (Fig. 2). This change in color is associated with accumulation of anthocyanins in vacuoles of subepidermal layers of the secretory parenchyma.

The surface of the nectary of white dogwood is slightly folded. This gland has similar diameter along its entire circumference (Fig. 3). The epidermis of the nectary is made up of irregular-shaped polygonal cells and a protruding outer wall (Figs. 4-6). Between the cells with a smooth cuticle, there were cells covered by a cuticle with longer or shorter cuticular striae, which formed characteristic "tacks" (Fig. 6). Numerous regularly distributed stomata are present in the epidermis of the nectary (Fig. 5). 

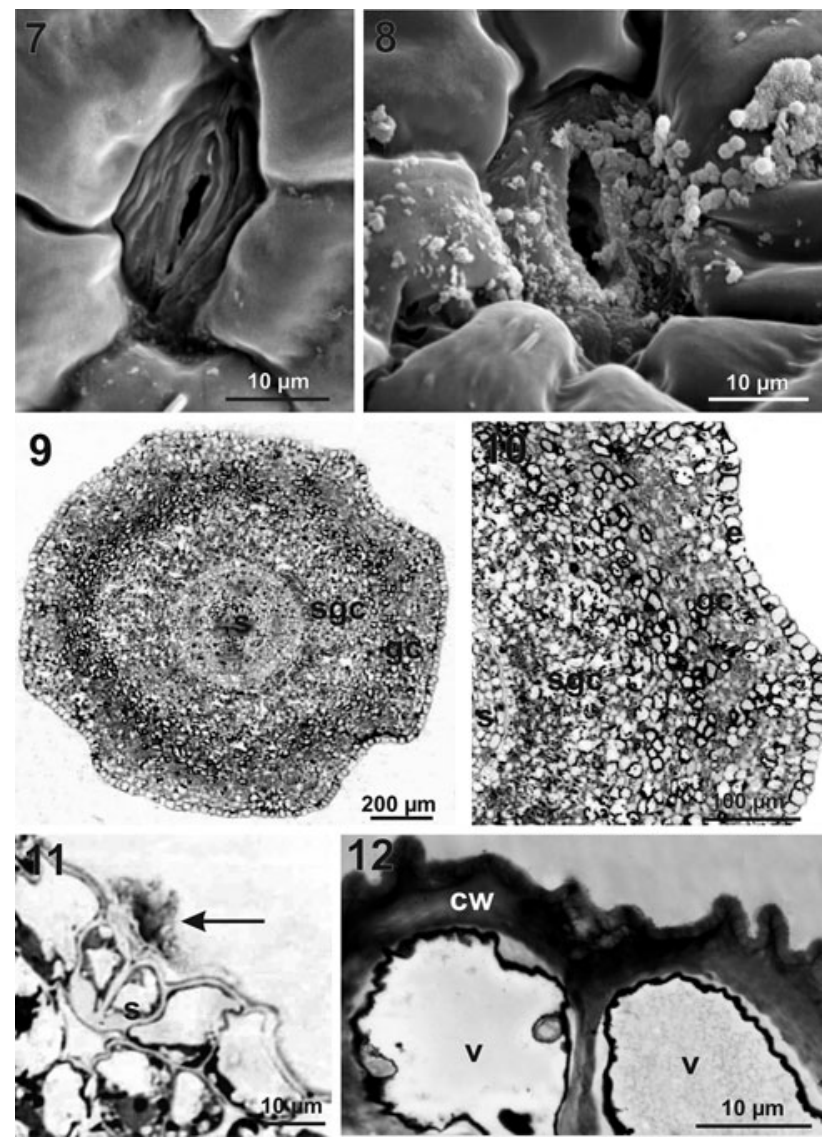

Plate II Figs. 7, 8 SEM. Stomata on the surface of the nectary of Cornus alba; 8 visible dried secretory product. Figs. 9, 10 LM. Transverse sections of the nectary $(n)$ and style $(s)$ of the Cornus alba flower with two kinds of secretory tissues: typical secretory cells and untypical secretory cells; $e$ epidermis, $g c$ glandular cells, $s g c$ subglandular cells. Figs. 11, 12 Epidermal cells of the nectary visible in LM (Fig. 11) and TEM (Fig. 12). Note a stoma $(s)$ with dried secretion (arrow), large vacuole $(v)$, and thick outer, tangential cell wall $(c w)$ with folded cuticle

On average, 118 stomata were observed per $1 \mathrm{~mm}^{2}$ of epidermis. The anomocytic stomata were situated in small depressions and usually surrounded by six epidermal cells with a smooth nonstriated cuticle (Fig. 7, 8). The pores by the outer cuticular ledges were open, and the surface of the cuticle covering the outer wall of the guard cells was frequently striated (Fig. 7, 8). Near the pores, small merging lumps and fluffy structures were observed, which could be dried secretion (Fig. 8).

The anatomical structure and ultrastructure of the cells of the nectary gland of white dogwood are untypical. The secretory tissue, when observed under light microscopy on longitudinal and transverse cross sections, is composed of a dozen cell layers with average thickness of $150 \mu \mathrm{m}$ and it does not form a typical tissue bed clearly distinguished by a uniform structure and color from the adjacent tissues (Fig. 9, 10).
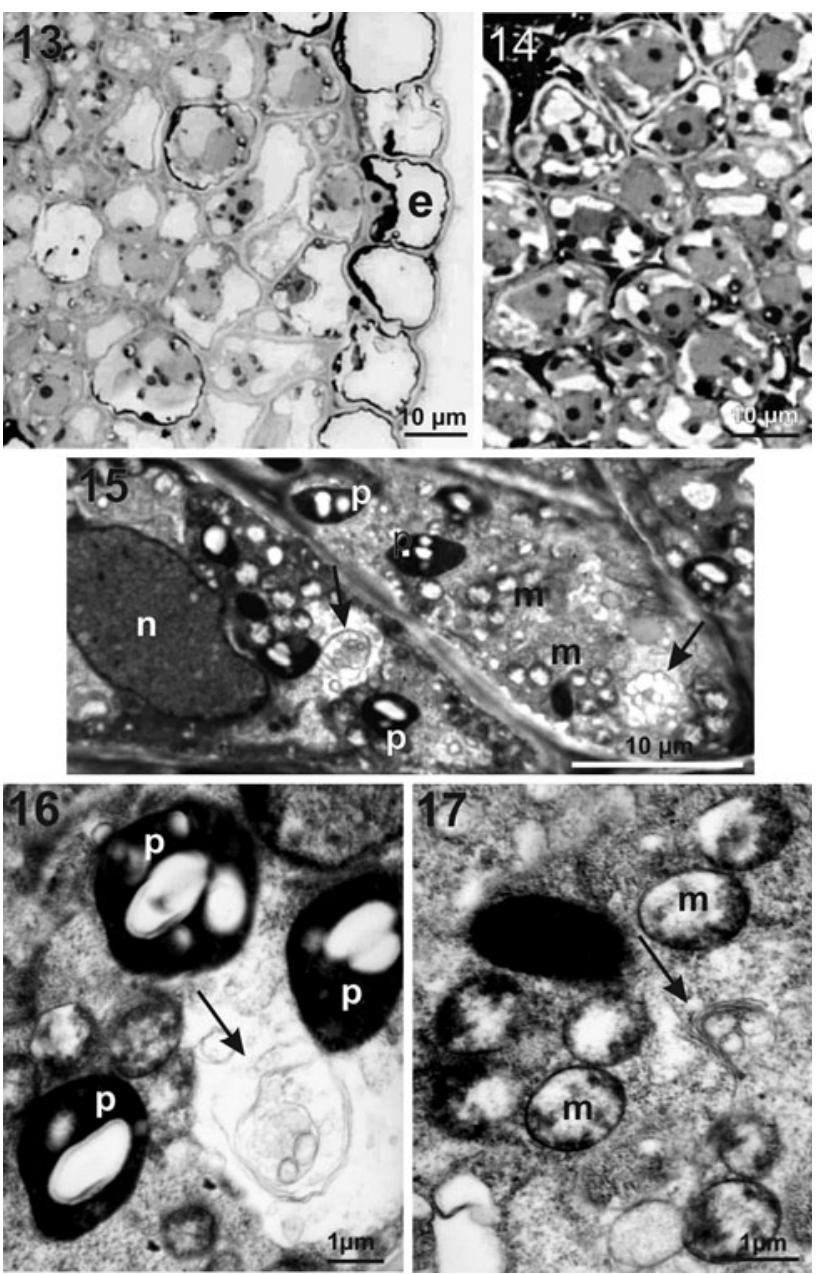

Plate III Figs. 13, 14 LM. Transverse section of nectary of Cornus alba. Typical secretory cells of the nectary with a nucleus, a large quantity of cell organelles, and different sized vacuoles; $e$ epidermis. Fig. 15 TEM. Nectariferous cells with dense cytoplasm, large nucleus $(n)$, mitochondria $(m)$, plastids $(p)$ containing starch grains and a myelin structure in the vacuole (arrows). Figs. 16, 17 TEM. Cytoplasm of a nectariferous cell with plastids with starch grains (p) (Fig. 16) and numerous mitochondria ( $m$ ) (Fig. 17), Arrows myelin structure in the vacuole

The subglandular parenchyma is characterized by a more loose arrangement of cells (Fig. 9, 10), its cytoplasm concentrated only near the walls, and the presence of large, centrally located vacuoles.

Nectarostomata were found in the nectary epidermis, and secretion was observed above the stomata (Fig. 11). The epidermal cells of the gland are marked by a quite large vacuole and a small amount of parietal cytoplasm (Fig. 12). The outer cell wall is characterized by greater thickness and cuticle folding (Fig. 12).

The nectary parenchyma of $C$. alba is not of photosynthetic type (numerous amyloplasts were observed in the secretory cells 2 days before anthesis, before nectar secretion began). The nectariferous layer is made up of 


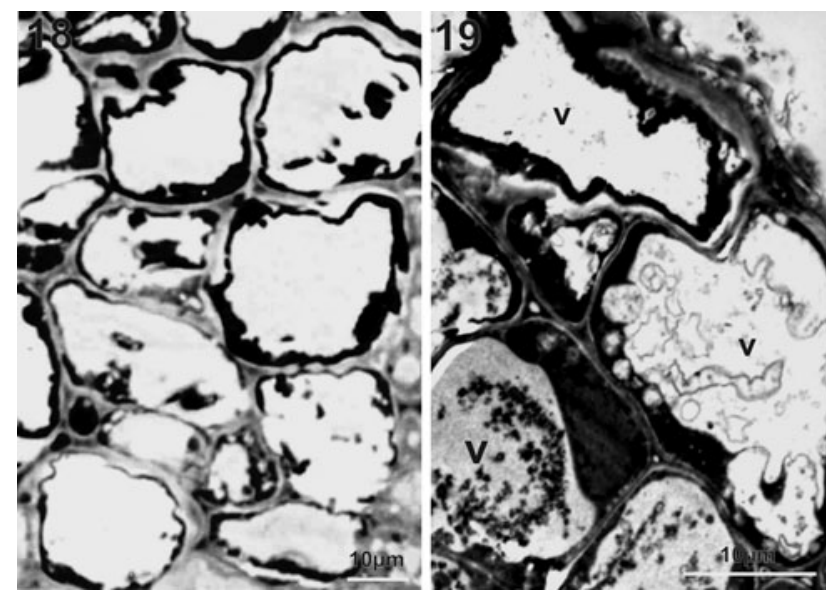

Plate IV Fig. 18 LM. Transverse section of nectary of Cornus alba. Untypical secretory cells of the nectary with large vacuoles and peripheral cytoplasm. Fig. 19 TEM. Untypical secretory cells. Visible large vacuoles $(v)$ with a membranous structure or electron-dense bodies and peripheral cytoplasm

cells of two types. The first type of cells are characterized by a protoplast organized typically for secretory activity (Figs. 13-15). They were distinguished by a bright color of their protoplasts and dense cytoplasm with a large nucleus and nucleoli (Figs. 13-15) as well as different sized vacuoles, sometimes containing myelin-like structures (Figs. 15, 16). Numerous and large amyloplasts containing starch grains were also visible in the cells (Figs. 15, 16). Numerous mitochondria, concentrated mainly near the cell walls, were also noted (Figs. 15, 17). In many cases, they were characterized by a more electron-transparent matrix. During nectar secretion, starch content decreased rapidly, and on the last day of anthesis, it was not observed in the amyloplasts.

The other type of cells, marked by a darker color and larger sizes, includes cells showed ageing symptoms, including visible disintegration of cell structures and strong vacuolization (Figs. 18, 19). In the region of the large, centrally located vacuoles, membranes and electrondense deposits were sometime observed (Fig. 19). The cytoplasm darkens and its volume decreases. The few structures visible in the cytoplasm, frequently with degenerated content, were concentrated near the cell walls (Figs. 18, 19). The mitochondria were almost entirely devoid of mitochondrial cristae. In addition, plastids containing starch grains were not observed in the cells concerned. The frequency of the occurrence of this type of degenerated cells increased as one moved away from the surface of the gland.

In the area of the nectary gland cells, no vascular tissue elements were observed. The nectary was irrigated by the vasculature of the flower receptacle.

\section{Discussion}

The nectary glands in white dogwood flowers are open nectaries, freely exposed to pollinating insects (Drabble 1927), and belong to the persistent nectaries (Smets 1988; Smets and Cresens 1988), remaining at the top of the fruit as a darkened region. Similar nectaries, in the form of a ring-like collar surrounding the style of the pistil, have also been observed in other genera from Cornaceae (except in Davidia) as well as in some representatives of different families (Asteraceae, Apiaceae, Ericaceae, Rubiaceae) (Takhtadžân 1980; Nicolson et al. 2007, and references wherein).

The observed change of color of the white dogwood nectary from cream-white to purple, resulting from accumulation of anthocyanins in some cells of the secretory parenchyma, seems related to photoprotection of the developing embryos. This is possible because the Cornus nectary is on top of the inferior ovary. Similar dependences were found (Vezza et al. 2006) in nectaries of Hedera helix. In different species of plants, similar change in nectary color (accumulation of not only anthocyanins but also $\beta$-carotenes) marks: (1) the duration of the ripening stage of nectary or (2) the end of the nectar secretion period or/and (3) informs pollinators about the unattractiveness of flowers (Belmonte et al. 1994; O'Brien et al. 1996; Thornburg 2007). Moreover, accumulation of anthocyanin in plant tissues, maybe as a response to low temperature, has been observed in autumn (Leng et al. 2000).

Nectar secretion through nectarostomata, as observed in white dogwood, is the most frequently described mode of nectar secretion in many plant species (e.g., Teuber et al. 1980; Durkee 1982; Sammataro et al. 1985; Davis and Gunning 1992; Zer and Fahn 1992; Weryszko-Chmielewska et al. 2003).

Some cells of the nectariferous tissue of dogwood, which form multilayered clusters, resembled a typical secretory tissue during anthesis. Vacuolized cells consist of dense cytoplasm with a large nucleus and numerous amyloplasts and mitochondria. A similar structure of the secretory tissue has also been described in other plant species (Freitas et al. 2001; Mačukanowić-Jocić et al. 2007; Cawoy et al. 2008; Paiva and Machado 2008). The presence of plastids containing starch grains suggests intensive synthesis of sugars which are accumulated in the cells of the nectariferous layer and then used for nectar production. Such correlations in nectariferous tissue cells are also reported by other authors (Durkee et al. 1981; Belmonte et al. 1994; Nepi et al. 1996; Weryszko-Chmielewska et al. 2003; Paiva and Machado 2008). 
The remaining cells of the dogwood gland, exhibiting symptoms of destruction, were characterized by a structure similar to that observed in cells of the nectaries in other plants after several days from the end of the nectar secretion stage (Zer and Fahn 1992; Nepi et al. 1996; O'Brien et al. 1996). According to those authors, the degradation of the cell structures and the high degree of vacuolization of the gland cells were accompanied by cell separation and the formation of intercellular spaces. The degradation of the mitochondrial cristae, which was found in the mitochondria of the cells of the nectary gland of white dogwood, as well as the absence of starch grains in the leucoplasts and the electron-dense deposits and membranous structures observed in the vacuoles demonstrate the absence of secretory activity of the degenerated cells in white dogwood. The occurrence of similar structures in the cells of the floral nectaries which ended the process of nectar secretion has been described in other species by O'Brien et al. (1996) and Paiva and Machado (2008). It seems that this part of the dogwood nectary cells ended the stage of secretory activity or that they did not perform this role at all. Recent literature data show that changes in the cells of the nectary during the secretion period do not take place synchronously (Gaffal et al. 2007; Nicolson et al. 2007, and references therein). In the nectary glands of dogwood, cells of different types, with different degrees of progress in deterioration processes, differing in content and color of protoplasts, may occur simultaneously. Moreover, the presence of cells with such degenerated content in white dogwood may suggest the advancing process of programmed cell death (PCD); this phenomenon has been described in cells of the nectaries of other plant species (Elias et al. 1975; Horner et al. 2003). Electron-dense deposits of unidentified chemical composition which were observed in vacuoles of $C$. alba secretory cells could have also been symptoms of PCD, too. Horner et al. (2003) reported on this in the nectary of Glycine max. This different pattern of cell degeneration is probably related to a very short time of nectar secretion.

The secretory tissue of $C$. alba flowers was not vascularized, but xylem vessels were observed in the vicinity of the nectary, in the flower receptacle. Many researches think that no special bundles may irrigate the nectaries, these being supplied by the vasculature of the organs located near them (e.g., Fahn 1988, 2000; Ma et al. 2002).

The structure of the floral nectaries of C. alba and a short time of nectar secretion partially explain the production of only a small amount of nectar by this gland (during the investigations, even an amount sufficient for analysis of nectar composition was not obtained using the pipette method) as well as slight interest in this reward from pollinating insects; a consequence of this may be the tiny number of fruits set in the inflorescences which was observed by the author of the present paper (unpublished data). The absence of nectar in the flowers of different Cornus species is confirmed by Kołtowski (2006), whereas this phenomenon is described by Ceska (1998) in Cornus canadensis. In some different plant species (e.g., Catalpa, Clytostoma, Cydista, Phryganocydia) (Rivera 2000, and references therein) a nectary can be recognized anatomically, but the nectary does not produce nectar. The lack of functional nectary has been associated with pollination by deception (Gentry 1980). However, other authors mention Cornus mas and C. obliqua as nectar-producing species. Their nectaries have a similar location and morphological structure as the white dogwood nectary (Szweykowska and Szweykowski 2003). There are no investigations of the structure of floral nectaries in other Cornus species and other representatives of Cornaceae. As reported by Petanidou et al. (2000), the structure of the nectary is closely correlated with the amount of nectar secreted. Furthermore, features such as temperature, humidity, soil type, wind, light requirements, plant age and viability, as well as location also affect the amount of nectar secreted and its composition (Howes 1979; Petanidou et al. 2000). Probably for these reasons, $C$. alba was determined to be a nectar-producing plant in the conditions of Asia (Howes 1979).

Open Access This article is distributed under the terms of the Creative Commons Attribution Noncommercial License which permits any noncommercial use, distribution, and reproduction in any medium, provided the original author(s) and source are credited.

\section{References}

Beck CB (2005) An introduction to plant structure and development. Cambridge University Press, New York, p 358

Belmonte E, Cardemil L, Kalin Arroyo MT (1994) Floral nectary structure and nectar composition in Eccremocarpus scaber (Bignioniaceae), a hummingbird-pollinated plant of central Chile. Am J Bot 8:493-503

Cawoy V, Kinet JM, Jacquaemart AL (2008) Morphology of nectaries and biology of nectar production in the distylous species Fagopyrum esculentum. Ann Bot 102:675-684

Ceska A (1998) The explosive pollination mechanism in Cornus canadiensis L. Bot Electr News 194. http://www.ou.edu/cas/ botany-micro/ben/ben194.html

Cronquist A (1988) The evolution and classification of flowering plants. New York Botanical Garden, New York

Davis AR, Gunning BES (1992) The modified stomata of the floral nectary of Vicia faba L. 1. Development, anatomy and ultrastructure. Protoplasma 166:134-152

Drabble EH (1927) Some flowers and their dipteran visitors. New Phytol 26:115-123

Durkee LT (1982) The floral and extrafloral nectaries of Passiflora. II. The extrafloral nectary. Am J Bot 69:1420-1428

Durkee LT, Gaal DJ, Reisner WH (1981) The floral and extrafloral nectaries of Passiflora. I. The floral nectary. Am J Bot 68:453-462

Elias TE, Rozich WR, Newcombe L (1975) The foliar and floral nectaries of Turnera ulmifolia L. Am J Bot 63:1349-1353 
Eyde RH (1988) Comprehending Cornus puzzles and progress in the systematics of the dogwoods. Bot Rev 54:233-351

Fahn A (1988) Secretory tissues in vascular plants. New Phytol 108:229-258

Fahn A (2000) Structure and function of secretory cells. Adv Bot Res 35:37-75

Freitas L, Bernardello G, Galetto L, Paoli AAS (2001) Nectaries and reproductive biology of Croton sarcopetalus (Euphorbiaceae). Bot J Linn Soc 136:267-277

Gaffal KP, Friedrichs GJ, El-Gammal S (2007) Ultrastructural evidence for a dual function of the floem and programmed cell death in the floral nectary of Digitalis purpurea. Ann Bot 99:593-607

Gentry AH (1980) Bignoniaceae, part I (Crescentieae and Tourrettieae). Flora Neotrop Monogr 25:1-150

Hofman J (1995) Drzewa magiczne. Drzewa lecznicze, Alfa Warszawa

Horner HT, Healy RA, Cervantes-Martinez T, Palmer RG (2003) Floral nectary fine structure and development in Glycine max L. (Fabaceae). Int J Plant Sci 164:675-690

Howes FN (1979) Plants and beekeeping. Faber \& Faber, Boston, London, p 39

Kołtowski Z (2006) Wielki atlas roślin miododajnych. Przedsiębiorstwo Wydawnicze Rzeczpospolita S. A., Warszawa

Konarska A (2009) The biology of flowering and structure of selected elements of Cornus alba L. flowers. Acta Agrobot 62:9-15

Leng P, Itamura H, Yamamura H, Deng XM (2000) Anthocyanin accumulation in apple and peach shoots Turing cold acclimation. Sci Hortic 83:43-50

Ma H, Xiao AJ, Cao R (2002) Developmental and antomic studiem on the floral nectaries of Tugarinova mongolica. Acta Bot Yunnan 24:638-644

Mačukanowić-Jocić MP, Rančić DV, Dajić Stevanovič ZP (2007) Floral nectaries of basil (Ocimum basilicum): morphology, anatomy and possibile mode of secretion. S Afr J Bot 73:636-641

Mert C, Soylu A (2009) Variations and abnormalities of stamen morphologies in cornelian cherry (Cornus mas L.) cultivars. Hort Sci (Prague) 36:109-116

Murrell ZE (1993) Phylogenetic relationships in Cornus (Cornaceae). Syst Bot 18:469-495

Nepi M, Ciampolini F, Pacini E (1996) Development and ultrastructure of Cucurbita pepo nectaries of male flowers. Ann Bot 78:95-104

Nicolson SW, Nepi M, Pacini E (2007) Nectaries and nectar. Springer, Dordrecht
O'Brien SP, Loveys BR, Grant WJR (1996) Ultrastructure and function of floral nectaries of Chamelaucium uncinatum (Myrtaceae). Ann Bot 78:189-196

Paiva EAS, Machado SR (2008) The floral nectary of Hymenaea stigonocarpa (Fabaceae, Caesalpinioideae): structural aspects during floral development. Ann Bot 101(1):125-133

Petanidou T, Goethals V, Smets E (2000) Nectary structure of Labiatae in telation to their nectar secretion and characteristics in a Mediterranean shrub community—does flowering time matter? Plant Syst Evol 225:103-118

Rivera G (2000) Nuptial nectary structure of Bignoniaceae from Argentina. Darwiniana 38:227-239

Sammataro D, Erickson EH, Garment MB (1985) Ultrastructure of the sunflower nectary. J Apicult Res 24:150-160

Seneta W, Doaltowski J (2004) Dendrologia. Wyd Nauk PWN, Warszawa

Smets E (1988) La présence des "nectaria persistentia" chez les Magnoliophytina (Angiospermes). Candollea 43:709-716

Smets E, Cresens E (1988) Types of floral nectaries and the concepts "character" and "character-state" - a reconsideration. Acta Bot Neerl 37:121-128

Spurr AR (1969) A low-viscosity epoxy resin embedding medium for electron microscopy. J Ultrastruct Res 26:31-43

Szweykowska A, Szweykowski J (2003) Słownik botaniczny. Wiedza Powszechna, Warszawa

Takhtadžân AL (ed) (1980) Žizn' rastenij. Tom V (1), Cvetkovye rasteniâ. Prosveščenie, Takhtadžân A. L. Moskva

Teuber LR, Albertsen MC, Barnes DK, Heichel GH (1980) Structure of floral nectaries of alfalfa (Medicago sativa L.) in relation to nectar production. Amer J Bot 67(4):433-439

Thornburg R (2007) Molecular biology of the Nicotiana floral nectary. In: Nicolson SW, Nepi M, Pacini E (eds), Nectaries and nectar. Springer, Dordrecht, pp 265-288

Vezza M, Nepi M, Guarnieri M, Artese D, Rascio N, Pacini E (2006) Ivy (Hedera helix L.) flower nectar and nectary ecophysiology. Int J Plant Sci 167:519-527

Weryszko-Chmielewska E, Masierowska ML, Konarska A (2003) Characteristics of floral nectaries and nectar in two species of Crataegus (Rosaceae). Plant Syst Evol 238:33-41

Zer H, Fahn A (1992) Floral nectaries of Rosmarinus officinalis L., structure, ultrastructure and nectar secretion. Ann Bot 70:391-397

Zhuang X, Klingeman WE, Hu J, Chen F (2008) Emission of volatile chemicals from flowering dogwood (Cornus florida L.) flowers. J Agric Food Chem 56:9570-9574 